\title{
Understanding the Role of Packaging Elements on Buying Detergent Powder in Dhaka City: A study on Bangladesh
}

\author{
Md. Ashaduzzaman \\ Faculty of Business Administration, Eastern University \\ Farzana Mahbub \\ Faculty of Business Administration, Eastern University
}

\begin{abstract}
Packaging acts as the salient salesman for tangible products. The verbal and nonverbal elements of packaging perform as the tool of sales promotion because of changing self-service and changing consumer's lifestyle. So, it performs a significant role in creating marketing communication and influencing consumer's purchase decision in detergent industry like other industry. Thus the paper aims to know the role of packaging on buying detergent powder in Bangladesh. Considering the impact of various elements of packaging on purchasing detergent powder, a conceptual framework was developed by extensive literature review and tested by using structural equation modeling taking 200 usable questionnaires. The result shows six components of packaging: Packing Color, Background Image, Font Style, Wrapper Design, Printed Information, and Packing Innovation that have impacts on purchase decision of detergent powder in Dhaka City.
\end{abstract}

Keywords: Bangladesh, Dhaka City, Packaging, Detergent Powder, Buying Behavior, and Impact.

\section{Background}

Packaging is a relevant tool in marketing and it is especially important in creating competitive advantages (Rundh, 2009). Nowadays competitive environment has created the more importance of packaging due to increasing self-service and changing consumers' lifestyle. Firms all over the world are giving more concern of packaging, sometimes it acts as salesman in giving required information to customers. According to (Rundh, 2005), package attracts consumer's attention to particular brand, enhances its image, and influences consumer's perceptions about product. Package also imparts unique value to products (Underwood et al. 2001; Silayoi \& Speece, 2004) and works as a tool for differentiation. Thus package performs an important role in marketing communications. The definitions of 'packaging' vary and range from being simple and functionally focused. Packaging can be defined quite simply as an extrinsic element of the product (Olson and Jacoby 1972). According to (Arens 1996), 
Packaging is the container for a product, encompassing the physical appearance of the container and including the design, color, shape, and labeling. In this context, several authors highlight the importance of studying the relationship between the quality attribute of packaging and its effects on purchasing behavior (Oliver, 1997; L€ofgren and Witell, 2005). Understanding the buying behavior of a consumer is at the heart of commercial success in today's competitive markets (Estiri et al., 2010). Packaging was one of the critical factors that affected the purchasing behavior (Silayoi and Speece, 2007).

Laundry detergent or washing powder is a type of detergent (cleaning agent) that is added for cleaning laundry. In common usage, "detergent" refers to mixtures of chemical compounds including which are similar to soap but are less affected by "hard water." In most household contexts, the term detergent refers to laundry detergent vs. hand soap or other types of cleaning agents. Most detergent is delivered in powdered form. Inhabitants of the Dhaka City prefer detergent powder than soap in washing clothes. Comparing with soaps, more detergent brands are available in the city.

Dhaka with more than 18 million people generates more demand for detergent powder (Wikipedia, 13-05-2105). Dhaka experiences a hot, wet, and humid tropical climate. In addition, the city has a distinct monsoonal season with an annual average temperature of $25^{\circ} \mathrm{C}\left(77^{\circ} \mathrm{F}\right)$ and monthly means varying between $18^{\circ} \mathrm{C}\left(64^{\circ} \mathrm{F}\right)$ in January and $32{ }^{\circ} \mathrm{C}\left(90^{\circ} \mathrm{F}\right)$ in May, steering more demands for detergent powder to have clean clothes. Thus the paper aims to know the role of packaging in buying detergent powder for economic importance.

Synthesizing of previous literature shows more works on packaging. For instance, (Gomez et.al., 2015) showed the importance of packaging in purchase and usage behavior. In addition, they evaluated packaging's technical, functional and informative attributes on customer's satisfaction and loyalty, According to (Aday and Yener, 2014), glass packages attracted the consumers with their protective structure, transparency, and healthy nature: whereas plastic and paperboard packages attracted the consumers with their resistance to physical impacts and easy-to-use abilities. Besides these, there is a paper that focuses on one element of packaging. For example, Kauppinen and Räisänen (2014) explored the impact of packaging color on consumer attention and product perception. The communication exchange between the package elements and the consumer determined the acceptability of products (Venter et al., 2011). Various authors have emphasized the importance of packaging from a marketing perspective (Peters-Texeira and Badrie, 2005), even defining it as the fifth "P" of the marketing mix (Kotler and Keller, 2006). Packaging acts as vehicle for communication and includes attributes such as color, design, form and message (Silayoi and Speece, 2004, 2007). This role has increased its relevance, especially because of the rise of self-service establishments.

Furthermore, a corpus of papers is also found regarding the impact of packaging strategy on single product. For example, (Lunardo and Guerinet, 2007) investigated the influence of labeling on wine consumption and its authenticity. In addition, there are available works such as glass packages (Aday and Yener, 2014) and packaging of immediate consumed milk (Gomez et.al.,(2015). Interestingly, there is a research about the impact of different elements of packaging on consumer behavior (Deliya \& 
Parmar, 2012). On the other hand, a research on washing powder shows the impact of the position of visuals in different corners of the packaging on product perception (Rompay and Veltkamp, 2014). However, there is no research on the impact of packaging elements on detergent powder or washing powder. Henceforth, all previous papers introduce the unexplored research on the role of packaging elements on detergent powder.) Thus the study explores the following packaging elements of detergent powder (shown in the figure I) through comprehensive literature review. The figure will assist the readers to understand clearly the components of packaging elements.

The rest of the article is structured as follows: First, a research framework explaining the packaging factors that can affect buying of detergent powder is presented. Next, the procedures used to test the hypothesized effects of these factors on detergent powder buying are described. The findings of the study are then presented. Finally, the article concludes with a summary of the study's research contributions, marketing implication, and directions for future research.

\section{Buying Decision Framework}

Packaging as a tool for communication was investigated by (Butkeviciene et al. 2008; Gonzalez, Thorhsbury \& Twede 2007; Vila \& Ampuero 2007; Nancarrow, Wright \& Brace, 1998; Prendergast \& Pitt, 1996; Smith \& Taylor, 2004; Underwood et al. 2001; Silayoi \& Speece, 2004; Underwood, 2003; Vazquez, Bruce \& Studd, 2003; Ampuero \& Vila, 2006). Consequently the role of package in marketing communications increases: it must attract consumer's attention and transmit adequate value of product to consumer in the short period right in the place of sale. Therefore there is a necessity to explore package and its elements in more detail in order to understand which of these elements are the most important for consumer's purchase decision. Different authors showed different views regarding the elements of packages. According to (Smith \& Taylor 2004), there are six variables that must be taken into consideration by producer and designers when creating efficient package: form, size, color, graphics, material, and flavour. Similarly, (Kotler, 2003) distinguishes six different elements such as size, form, material, colour, text, and brand those must be evaluated when employing packaging decisions. (Vila \& Ampuero, 2007) similar to (Underwood, 2003) distinguished two blocks of package elements: graphic elements (colour, typography, shapes used, and images) and structural elements (form, size of the containers, and materials). 


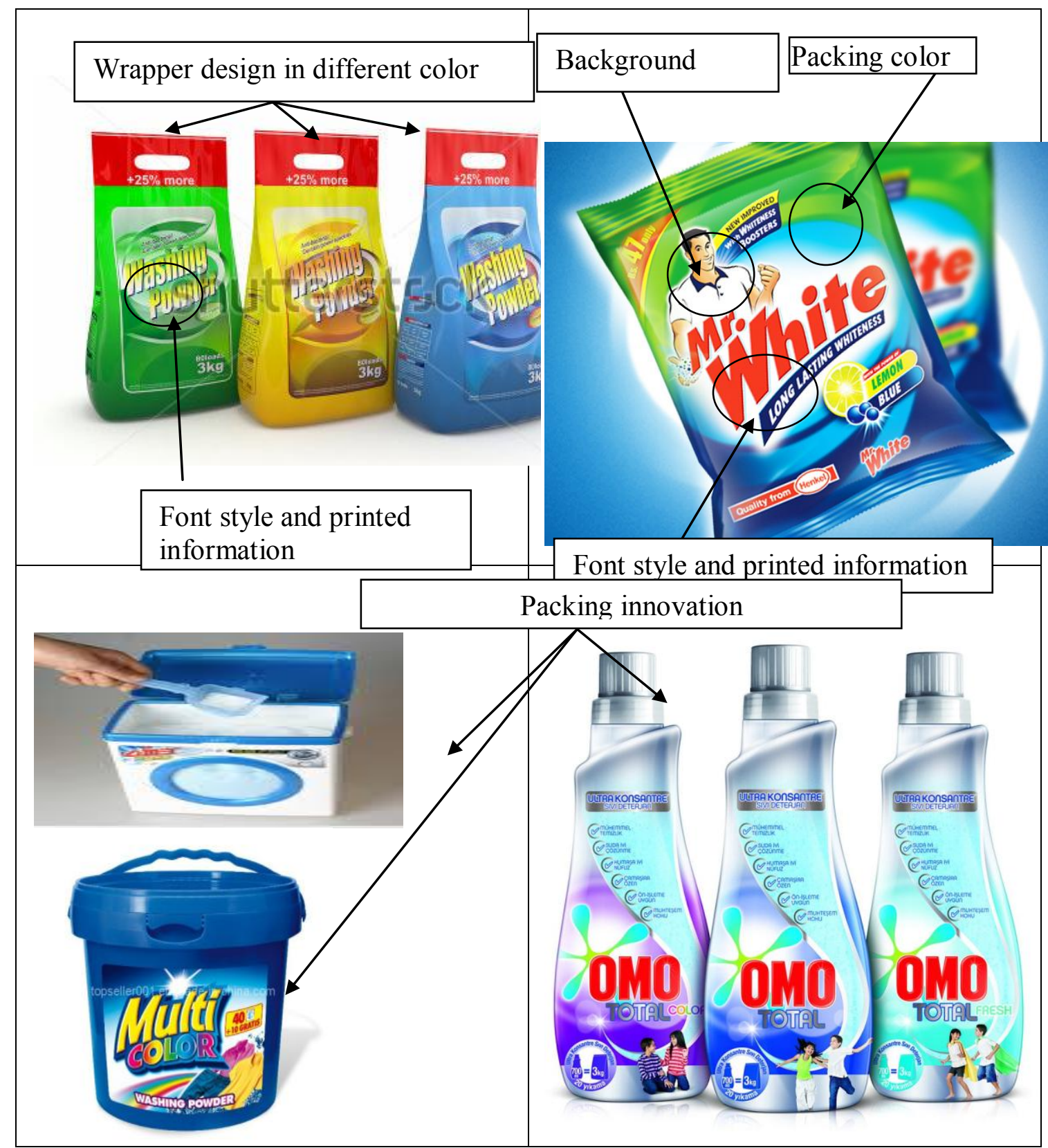

Figure 1: Packaging elements of Detergent Powder

Sources: Authors

It should be noticed that these two blocks, similar to classification of (Smith \& Taylor, 2004) do not include verbal elements of package. (Rettie \& Brewer, 2000) stressed out the importance of proper positioning of elements of package, dividing the elements into two groups: verbal (for example, brand slogans) and visual (visual appeal, picture, etc.) elements. In addition, (Silayoi \& Speece, 2004; 2007) divide package into two categories of elements: visual elements (graphics, colour, shape, and size) and informational elements (information provided and technology). According to (Silayoi \& Speece, 2004), visual elements are related with affective aspect of consumer's decision making process, while informational elements are related with cognitive one. Thus, based on the previous literature, a theoretical framework (shown in figure 2) containing six elements of packaging (color, background image, font 
style, wrapper design, printed information, and packing innovation) has been developed to know the impact of packaging on buying detergent powder.

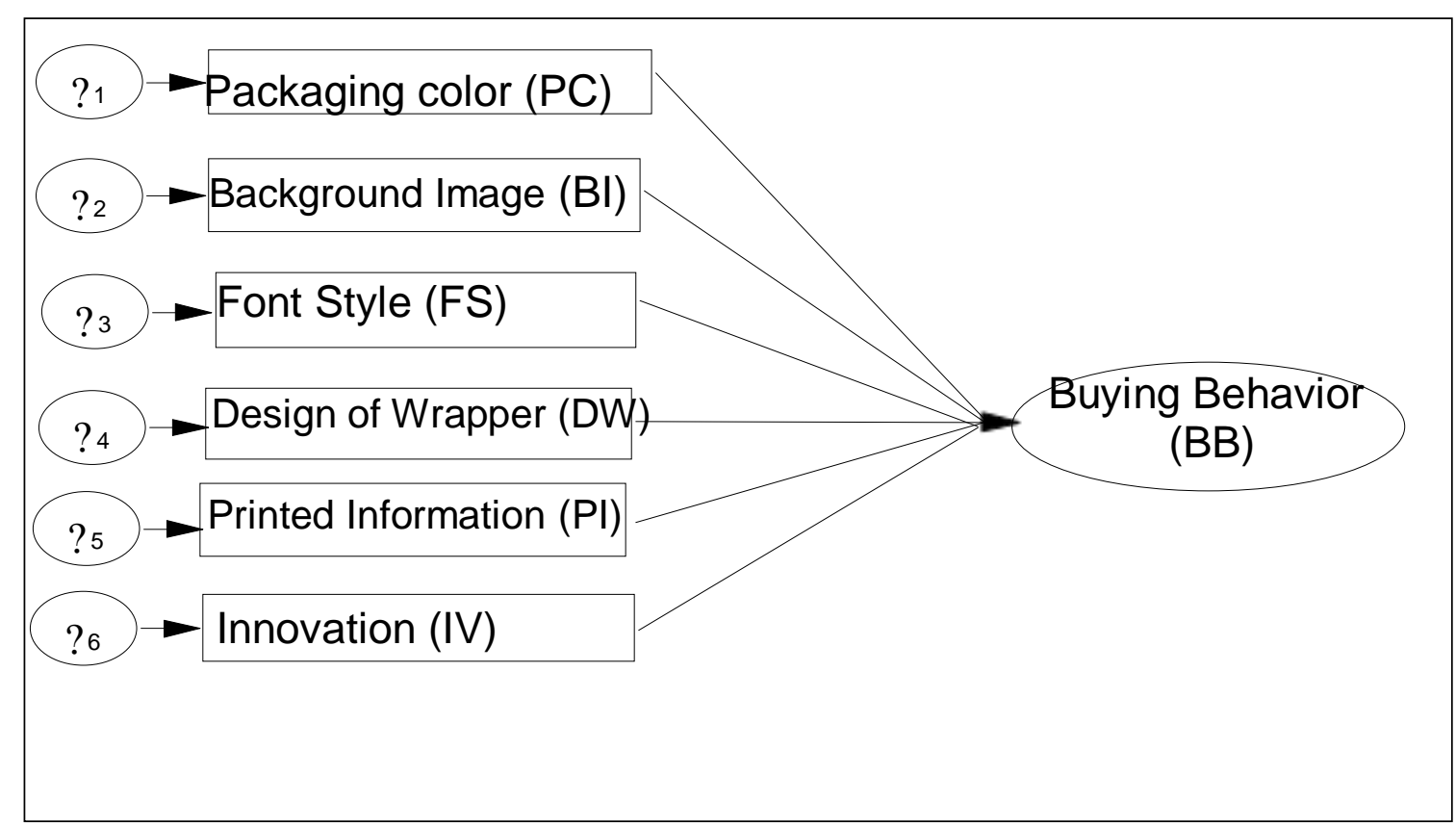

Figure II: A conceptual framework of packaging role in detergent powder buying.

\section{Packaging color}

Color is a key element of design due to the fact that it is usually vivid and memorable. (Cheskin, 1957) says that the selection of the colors and color combinations is a necessary process for creating a good design package. Color plays an important role in a potential customer's decision making process, certain colors set different moods and can help to draw attention. One good example of successful use of color psychology is in the Apple iPod advertisements; they use simple tri tone color schemes of black, white and a bright background. Packaging applications have many color-coded messages which are associated with the particular product category (Stewart, 2004). Packaging color is one of different non-verbal elements that induce consumers to make buying decision (Vila \& Ampuero, 2007; Underwood, 2003). Dissimilar or novel colors may attract and be preferred by those customers who like novelty (Kauppinen-Räisänen et al., 2010). The right choice of colors is an important factor in creating the impression needed to influence brand and product selection (Gofman et al., 2010). Female are more attracted by color rather than male (Radel off DJ, 1990) in photography, on the other hand male are more attracted by soft bright color. Thus the following hypothesis can be concluded:

H1: There is a positive impact of packaging color on detergent powder buying behavior. 


\section{Background image}

Background image means the character or picture of celebrities, or cartoon or other images used in the packaging. The background image specifies the picture of the product in its packaging. (Silayoi \& Speece, 2004; Bloch 1995; Grossman \& Wisenblit 1999; and Butkeviciene et al., 2008) highlight the impact of packaging graphic on consumers' decision to buy brands. Image appears on the color of package, so the color should be bright enough. While verbal elements (printed information) transmit information which has an effect on consumer's cognitive orientation, Visual elements (image and picture) of package transmit information which affects consumer's emotions (Silayoi \& Speece, 2004). Thus it can be concluded that

$\mathrm{H} 2$ : There is a positive impact of background image on detergent powder buying behavior.

\section{Font style}

Font Style means the pattern of writing in the packages. The font style of packaging grabs customer attraction. The up gradation of IT technology has supported this feature. (Rettie \& Brewer, 2000) stressed out the importance of proper positioning of elements of package, especially the impact of visual elements (font style, color) on buying behavior. In the similar way package elements were classified by (Butkeviciene, at. el., 2008). They concluded that non-verbal elements (graphics, font pattern) like verbal elements influence the buying decision process. The successful companies have best practices of the font styles. They hire specialist in composing which create mind blowing and attractive font styles. The attractive package has innovative font style. So we can say that there is relation between font style and buying behavior.

H3: There is a positive impact of font style on detergent powder buying behavior.

\section{Design of wrapper}

It is the type of packaging that differentiates a brand from the competition. The designs of wrapper vary from brand to brand and product to product respectively. Wrapper is a one type of packaging such as a flat sheet made out of paper, cellophane or plastic to enclose an object. The overall design also plays a vital role in attracting the consumer. (Vila \& Ampuero, 2007) emphasized the structural elements of packaging such as the form, size of the containers, and materials. In the same way, (Underwood, 2003) discovered the importance of the structural and graphical elements of packaging on buying behavior. The companies try their best to create attractive design of packaging. So the following hypothesis is derived:

H5: There is a positive impact of design of wrapper on detergent powder buying behavior. 


\section{Printed Information}

Packaging acts as a salient salesman for its given information. Different color, style, and shade are used to present information. The labels or information on packages are important components of the overall marketing mix and can support advertising claims, establish brand identity, enhance name recognition, and optimize shelf space allocations (Mitul et al., 2012). The consumer can change the decision on the basis of information printed on the packaging. In case of daily purchased FMCG (Fast Moving Consumer Goods), the consumer evaluates products on the basis of printed information. Now the 3D technology has given the opportunity to write stylist information on the packaging that draws attention of purchasers. Thus it is hypothesized that

H5: There is a positive impact of printed information on detergent powder buying behavior.

\section{Innovation}

Innovation means a large amount of packing methods. The packing method depends on the actual product. However, Innovation should not undermine packaging's primary role, which is to protect the product and to attract and inform consumers. Plastic or glass bottles and jars are used as a package for beverages. Steel canning package is a method of preserving perishable food. Hence, the package varies from the product categories as well as from the materials and technical methods it requires. Innovative packaging may actually add value to the product if it meets a consumer need such as portion control, recyclability, tamper-proofing, child-proofing, easyopen, easy-store, easy-carry, and non-breakability. Manufacturers today strive to have packaging that maintains the key equities of the brand that have stand out appeal on the retailer's shelf, and that are sustainable but with lower production costs. The customer can adopt product on the basis of its innovative packaging, which shows the relation between buying behavior and innovation of packaging. So the following hypothesis can be concluded:

H7: There is a positive impact of innovation on detergent powder buying behavior.

\section{Methodology}

\section{Sampling}

The target population consists of Bangladeshi people who are using detergent powders. So the unit of analysis is the users of detergent powder. Collecting data from every place of the city is impossible, that's why only three areas such as Dhanmondi Residential Area, Elephant Road and Kamlapur have been selected purposively. Interviewers were used to reach 300 respondents with the pretesting questionnaire but ultimately the realized sample size was 230 with 200 usable questionnaires, representing $67 \%$ response rate. Finally all 200 questionnaires as per recommendation of (Hair et al.1995) were analyzed by using structural equation modeling for testing 
hypotheses. The resulted sample can be said as purposive sample. Both male and female were targeted as respondents but within age 16-65.

\section{Data Collection}

The initial questionnaires were pretested with a convenience sample of 20 detergent buyers with a collaborative participant pretesting method described by Cooper and Schindler (2006). Data for the main study was collected during December 2013 using purposive sampling techniques interviewed by trained interviewers. A structured questionnaire was designed for data collection through face to face interview with respondents to whom no incentives were given. The Table 1 shows the sociodemographic profile of respondents who participated in the study. The sample was male dominated where $62 \%$ were male and $32 \%$ were female and majority of respondents fell within 18-30 age.

Table1: Demographic profile of respondents.

\begin{tabular}{|c|c|c|c|c|c|c|}
\hline \multicolumn{2}{|c|}{ Gender } & \multicolumn{5}{|c|}{ Age } \\
\hline Male & Female & $16-25$ & $26-35$ & $36-45$ & $46-55$ & $56-65$ \\
\hline $62 \%$ & $38 \%$ & $46 \%$ & $18 \%$ & $17.5 \%$ & $13 \%$ & $4.5 \%$ \\
\hline
\end{tabular}

\section{Measurement}

A descriptive quantitative research design was deemed perfect to evaluate the research issues. The research instruments and variables shown in Table 2 have been developed by comprehensive relevant literatures review. So the measures used in the research framework such as Packaging color, Background Image, Font Style, Design of wrapper, Printed Information, and Innovation were taken as the research constructs. Each construct has two or three components or indicators. A five-point Likert-type scale $(1=$ strongly disagree to $5=$ strongly agree $)$ was employed to measure variable items for the research questionnaire. Finally, the quantitative data were processed and analyzed by Structural Equation Modeling (SEM, version 12) with a 0.05 level of significance for all of the statistical assessments.

\section{Results}

\section{Validity and Reliability Test}

Confirmatory factor analysis was used to test the convergent validity for the whole set of constructs. After we dropped some items that possessed either low factor loadings or cross loadings, the confirmatory model fit the data satisfactory. The model provides a satisfactory fit to the data because all MI values are less than 3.84. In addition, the fit indices are as follows: comparative fit index $(\mathrm{CFI})=.70$; Coefficient of determination $(\mathrm{CD})=0.53$; and root mean square error of approximation $(\mathrm{RMSEA})=$ .06 , indicating the unidimensionality of the measures (Anderson and Gerbing, 1988; Hair et al., 1998). Thus the measures of the data demonstrate adequate convergent validity.

Cronbach's $\alpha$ was used for testing the reliability of measures. Based on the benchmark built by (Bagozzi and Yi, 1988), cronbach's $\alpha$ over .60 indicates high 
construct reliability. In the present research, all the values of cronbach's $\alpha$ are .62 which demonstrate adequate construct reliability for the testing data.

Table 2: Measurement scale

\begin{tabular}{|c|c|c|}
\hline Concept & Indicator & Statement \\
\hline Packaging Color (PC) & $\begin{array}{l}\text { PC1 } \\
\text { PC2 }\end{array}$ & $\begin{array}{l}\text { When I buy detergent powder, the body color is what first catches my sight. } \\
\text { The attractive color combination of fonts influences my purchasing decision. }\end{array}$ \\
\hline Background Image (BI) & $\begin{array}{ll}\text { BI1 } & \text { Character } \\
\text { BI2 } & \text { Celebrities }\end{array}$ & $\begin{array}{l}\text { I value the packaging because it carries the relevant logo/image of animal or trees. } \\
\text { The image of celebrities on detergent packages inclined me to a particular brand. }\end{array}$ \\
\hline Font Style (FS) & $\begin{array}{l}\text { FS1 Writing } \\
\text { FS2 Graphics }\end{array}$ & $\begin{array}{l}\text { The pattern of writing that is the visual elements creates attraction on detergent powder. } \\
\text { I prefer to buy the detergent powder having packaging with the chart or illustration. }\end{array}$ \\
\hline $\begin{array}{l}\text { Design of Wrapper (DW } \\
\text { pack. }\end{array}$ & $\begin{array}{l}\text { DW1 Form } \\
\text { DW2 Container }\end{array}$ & $\begin{array}{l}\text { The form of packaging influences me to adhere to a particular detergent brand. } \\
\text { I prefer to buy a brand sold with different sizes of container like mini pack or family }\end{array}$ \\
\hline Printed Information (PI) & $\begin{array}{l}\text { PI1 Label The } \\
\text { PI2 Features }\end{array}$ & $\begin{array}{l}\text { label or information regarding on packaging regarding } \mathrm{X} \text { brand influences my decision. } \\
\text { am influenced to buy a brand with sufficient information on product features. }\end{array}$ \\
\hline Innovation (IV) & $\begin{array}{l}\text { IV1 Easy Open } \\
\text { IV2 Tamper Proof } \\
\text { IV3 Non-Breakabi }\end{array}$ & $\begin{array}{l}\text { The packaging with the system of easy opening stimulates me to buy the brand. } \\
\text { fing I prefer the packet that can be put in any places of the house. } \\
\text { ility The benefit of non-breakability of the packaging influences me to buy a brand. }\end{array}$ \\
\hline Buying Behavior (BB) & $\begin{array}{l}\text { BB1 Purchase } \\
\text { BB2 Recommend }\end{array}$ & $\begin{array}{l}\text { I buy the detergent powder by seeing the packaging. } \\
\text { I will recommend others about the packaging of the detergent powder. }\end{array}$ \\
\hline
\end{tabular}

\section{Descriptive statistics}

In most cases frequency counts are only the univariate descriptive statistics required for measuring variables (Kotze, 2007). Statistics shown in table 1 indicates that respondents within 16-35 are the largest purchasers of detergent powder.

The mean values presented at Table 3 show that respondents really consider Font Style and Wrapper Design with mean $3.71 ; 3.70$ and standard deviation $.92 ; .85$ correspondingly during buying detergent powder. On the other hand, respondents place less effort on packing innovation having mean 3.55 and standard deviation .95 respectively. Ultimately, respondents consider all aspects less or more during purchasing detergent powder.

Table 3: Descriptive analysis of the constructs used in the study.

\begin{tabular}{|l|c|c|}
\hline \multicolumn{1}{|c|}{ Constructs } & Mean(M) & Standard Deviation(SD) \\
\hline Packing Color & 3.55 & .92 \\
\hline Background Image & 3.66 & .94 \\
\hline Font Style & 3.71 & .85 \\
\hline Wrapper Design & 3.70 & .92 \\
\hline Printed Information & 3.68 & .99 \\
\hline Packing Innovation & 3.55 & .95 \\
\hline
\end{tabular}

Note: Scale value ranges from 1 (Strongly Disagree) to 5 (Strongly Agree), the higher the mean, the higher the agreement with the particular aspect. 


\section{Hypotheses Test}

The paper aims to show the impact of packaging factors on detergent buying by Bangladeshi consumers. Thus six exogenous variables such as packing Color, background image, font style, wrapper design, printed information, and packing innovation were used to know the effect on detergent powder buying. So the technique of structured equation modeling (SEM) was used to examine the causal relation between the exogenous variables and the endogenous variable: detergent powder buying. The output gives us standardized factor loading for each of the seven observed variables as well as their relation level, significance, and confidence intervals. All path coefficients and results of hypotheses testing are summarized in Table 4 and Figure 3.

Table 4: Standard Coefficients and T-value for each Path

\begin{tabular}{|l|l|c|c|c|}
\hline \multicolumn{2}{|c|}{ Hypotheses } & $\begin{array}{c}\text { Path } \\
\text { Coefficient }\end{array}$ & t- Value & Result \\
\hline H1 & $\begin{array}{l}\text { Packing Color<- Buying } \\
\text { Behavior }\end{array}$ & .59 & $2.98 * * *$ & Supported \\
\hline H2 & Background<- Buying Behavior & .55 & $2.82 * * *$ & Supported \\
\hline H3 & Font Style<- Buying Behavior & .57 & $2.94 * * *$ & Supported \\
\hline H4 & $\begin{array}{l}\text { Wrapper Design<- Buying } \\
\text { Behavior }\end{array}$ & .41 & $.52 * * *$ & Supported \\
\hline H5 & $\begin{array}{l}\text { Printed Information<- Buying } \\
\text { Behavior }\end{array}$ & .43 & $.99 * * *$ & Supported \\
\hline H6 & $\begin{array}{l}\text { Packing Innovation<- Buying } \\
\text { Behavior }\end{array}$ & .55 & $2.29 * * *$ & Supported \\
\hline
\end{tabular}

Figure 3: The path diagram of standardized solution.

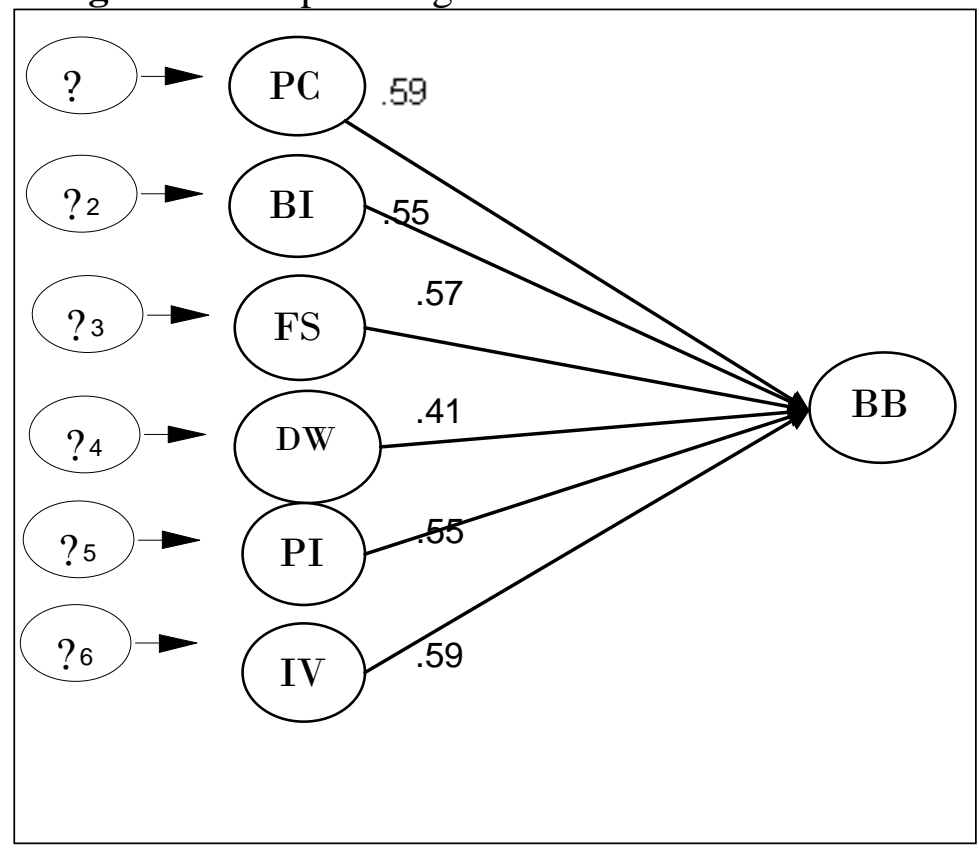


The path coefficient shows the direct effect of independent variables on dependent variable. Consistent with our prediction, packing Color, background image, font style, wrapper design, printed information, and packing innovation exhibit significant impact on detergent buying by Bangladeshi consumers. Therefore, H1, H2, H3, H4, $\mathrm{H} 5$, and $\mathrm{H6}$ are supported indicating that Bangladeshi consumers consider these factors in buying detergent powder.

\section{Discussion and Conclusion}

The paper aims to contribute to the theoretical understanding of the impact of the packaging on buying decision of detergent powder in Bangladesh by examining the six major researches constructs; that is the effects of packing Color, background image, font style, wrapper design, printed information, and packing innovation on detergent powder buying. To our knowledge, it is the first study that demonstrates the factors affecting buying decision of Bangladeshi consumers in detergent powder. The conceptual framework was first developed based on the rigorous literature review and then finally tested based on our research. Now the framework is applicable for identifying the role of packaging affecting buying decision of Bangladeshi consumers for detergent powder. The path diagram of standardized solution shows the direct effect of six packaging variables on buying detergent powder.

Package could be treated as one of most valuable tool in today's marketing communications in detergent powder, necessitating more detail analysis of its elements and an impact of those elements on consumers buying behavior. Appropriate and vivid picture or packaging color delivers a happy feeling and this finding is also consistent with that of (Vila \& Ampuero, 2007). All these elements contribute important effort to catch consumers' attention and interest. Besides each element's single function, a good combination of those elements may let detergent powder more eye-catching and attractive. The impact of package and its elements on consumer's purchase decision can be revealed by analyzing an importance of its separate elements for consumer's choice. So the tested framework has revealed that elements of package are the most important for consumer's purchase decision for detergent powder.

\section{Managerial implication}

Detergent powder is one of the profitable Fast Moving Consumer Goods (FMCG). So packaging is valuable for brand equity, product differentiation, market segmentation, new product introduction, pricing, and promotion. All the marketing units should pay attention for good packaging. However, poor packaging is one of the causes of different brands' failure in the market. It is necessary to set the packaging standard and to implement accordingly for better protection and promotion of a brand. Basically with the help of packaging the manufacturers describe where it was made, when it was made, what it contains, and how to use it. Furthermore consumers are properly guided by label to use the brands. So the information given in the label and its value have to be highlighted while promoting the brand in the market.

\section{Limitations and Future Research}

The paper also has a lot of limitations. First, the sample respondents are not large enough for the study to make it generalizing for other countries. Next, the results 
reflected through the study limited its application for other products. Future study should be conducted for other fast moving consumer goods, home appliances, and electronic products. Finally, the research only focused on Bangladeshi users, so cross cultural research should be the future research also.

\section{References}

Aday, M. S., and Yener, U., (2014), "Understanding the buying behaviour of young consumers regarding packaging attributes and labels", International Journal of Consumer Studies, vol. 38 pp. 385-393

Ampuero, O. and Vila, N., (2006), "Consumer perceptions of product packaging", Journal of Consumer Marketing, vol. 23, no. 2, pp. 100-112.

Anderson, J. C. and Gerbing, D. W., (1988), "Structural equation modeling in practice: A review and recommended two-step approach", Psychological Bulletin, vol. 103, No. 3, pp. 411-423

Arens, F. W., (1996), Contemporary Advertising, Irwin, United States of America: Mcgraw-hill Higher Education.

Bagozzi, Richard P., and Youjae Yi. "On the evaluation of structural equation models." Journal of the academy of marketing science vol.16.1 pp. 74-94.

Bloch, P. H., (1995), "Seeking the ideal form: product design and consumer Response", Journal of marketing, vol. 59, pp. 16-29.

Bo Rundh, (2009), "Packaging design: creating competitive advantage with product packaging", British Food Journal , Vol. 111 Iss: 9, pp.988 - 1002.

Butkeviciene, V., Stravinskiene, J. and Rutelione, A., (2008), "Impact of consumer package communication on consumer decision making process" Inzinerine Ekonomika-Engineering Economics, vol.1, pp. 57-65.

Clive Nancarrow, Len Tiu Wright, Ian Brace, (1998) "Gaining competitive advantage from packaging and labelling in marketing communications", British Food Journal, Vol. 100 Iss: 2, pp.110 - 118.

Cooper, D. R., and Schindler, P. S., (2006), Business Research Methods (9th ed.), New York, Irwin: McGraw-Hill.

Deliya, M. M., and Parmer, B. J., (2012), "Role of packaging on consumer buying behavior-patan district", Global journal of management and business research, vol. 12, no. 10 , pp. $48-68$

Estiri, M., Hasangholipour, T., Yazdani, H., Nejad, H. J., \& Rayej, H. (2010), "Food Products Consumer Behaviors: Role of Packaging elements", Journal of Applied Sciences, Vol.10 (7), pp.535-543. 
Gofman, A., Moskowitz, H.R. \& Mets, T. (2010), "Accelerating structured consumer - driven package design". Journal of Consumer Marketing.

Gomez, M., Consuergra, D. M. and Molina, A., (2015), "The importance of packaging in purchase and usage behavior", International Journal of Consumer Studies, vol.39, pp. 203-211.

Gonzalez M. P., Thorhsbury S. and Twede D., (2007), "Packaging as a tool for product development: Communicating value to consumers", Journal of Food Distribution Research, vol. 38, no. 1, pp. 61-66.

Grossman, R. P., and Wisenblit, J. Z., (1999), "What we know about consumers' color choices", Journal of Marketing Practice: Applied Marketing Science, vol. 5, no. 3, pp. 78-88.

Hair, J. F. Jr., Anderson, R. E., Tatham, R. L., and Black, W. C., (1995), Multivariate Data Analysis (3rd ed.). New York: Macmillan Publishing Company.

History of Dhaka, Wikipedia, the free encyclopedia, 13-05-2105) http://en.wikipedia.org/wiki/Dhaka.

Jerry C. Olson and Jacob Jacoby (1972), "Cue Utilization in the Quality Perception Process", in SV - Proceedings of the Third Annual Conference of the Association for Consumer Research, eds. M. Venkatesan, Chicago, IL : Association for Consumer Research, Pages: 167-179.

Kauppinen-Räisänen, H. (2014), Strategic Use of Colour in Brand Packaging. Packag. Technol. Sci., vol.27, pp.663-676.

Kauppinen-Räisänen, H. \& Luomala, H.T. 2010. Exploring consumer's productspecific color meanings.

Kotler, P. \& Keller, K.L. (2006), Marketing Management. Pearson, Prentice Hall, New Jersey.

Kotzé, Theuns. "Guidelines on writing a first quantitative academic article." Department of Marketing and Communication Management, University of Pretoria (2007).

Lofgren, M. \& Witell, L. (2005), “Kano's theory of attractive quality and packaging”, Quality Management Journal, vol.12, pp.7-20.

Mitul M. Deliya and Bhavesh J. Parmar. (2012). Role of packaging on Consumer buying behavior -Patan District. Global Journal of management and business, vol.12 (10), pp.49-67.

Oliver, R.L. (1997) A Behavioral Perspective on the Consumer. McGraw Hill, New York. 
Peters-Texeira, A. \& Badrie, N. (2005), “Consumers' perception of food packaging in Trinidad, West”, International Journal of Consumer Studies, vol.29, pp.508-514.

Prendergast, G.; and Pitt, L., (1996), "Packaging, marketing, logistics and the environment: are there trade-offs?", International Journal of Physical Distribution \& Logistics Management, vol. 26, no. 6, pp. 60-72.

Radeloff, D.J., (1990), "Role of color in perception of attractiveness",. Department of Applied Human Ecology, Bowling Green State University, Ohio, vol. 43403, no. 71(1), pp. 151-60.

Rettie, R., Brewer, C., (2000), "The verbal and visual components of package design", Journal of Product Brand Management, vol. 9, no. 1, pp. 56-70.

Rundh, B., (2005), "The multi-faceted dimension of packaging”, British Food Journal, vol. 107, no. 9, pp. 670-684.

Silayoi, P., and Speece, M., (2004), "Packaging and purchase decisions: An exploratory study on the impact of involvement level and time pressure", British Food Journal, vol. 106, no. 8, pp. 607-628.

Silayoi, P., and Speece, M., (2007), "The importance of packaging attributes: a conjoint analysis approach", European Journal of Marketing, vol. 41, no. 11/12, pp. $1495-1517$.

Smith, P., and Taylor, J., (2004), Marketing communications: an integrated approach (4th edition). London: Kogan Page.

Stewart, B. 2004. Packaging Design Strategies. Second Edition. The UK: Pira International Ltd.

Underwood, R. L., Klein, N. M.and Burke, R. R., (2001), "Packaging communication: attentional effects of product imagery", Journal of Product \& Brand Management, vol. 10 , no. 7 , pp. 403-422.

Underwood, R. L., (2003), "The communicative power of product packaging: creating brand identity via lived and mediated experience", Journal of Marketing Theory and Practice, vol. Winter, pp. 62-76.

Van Rompay, T. J. L. and Veltkamp, M. (2014), Product Packaging Metaphors:

Effects of Ambiguity and Explanatory Information on Consumer Appreciation and Brand Perception. Psychol. Mark., vol.31, pp.404-415.

Vazquez, D., Bruce, M., and Studd, R., (2003), “A case study exploring the packaging design management process within a UK food retailer", British Food Journal, vol. 105, no. 9, pp. 602-617.

Venter, K. et al. (2011), “Consumers' perceptions of food packaging: an exploratory investigation in Potchefstroom, South Africa", International Journal of Consumer Studies, vol. 35, pp. 273-281. 
Vila, N. and Ampuero, O., (2007), "The role of packaging in positioning an orange juice", Journal of Food Products Marketing, vol. 13, no. 3, pp. 21-48. 